\title{
ANALISIS MODAL KERJA PADA UMKM (USAHA MIKRO KECIL DAN MENENGAH) DALAM MENINGKATKAN LABA USAHA
}

\author{
Elly Lestari ${ }^{1}$ dan Wilhelmus Rian Raja ${ }^{2}$ \\ 1,2 Jurusan Manajemen Universitas Tribhuwana Tunggadewi \\ Email: wilhelmusriand@gmail.com
}

\begin{abstract}
ABSTRAK
Penelitian ini bertujuan untuk mengetahui tingkat efektifitas pengelolaan modal kerja serta pengaruh modal kerja terhadap laba usaha pada UMKM took roti khususnya Toko Roti Fadilah yang terdapat di Jalan Raya Tlogomas Malang. Dalam penelitian ini metode yang digunakan yaitu penelitian kuantitatif dengan pendekatan deskriptif. Populasi dan sampel dalam penelitian ini yaitu laporan keuangan selama lima periode dari tahun 2013 - 2017.

Pengumpulan data berbentuk dokumentasi dari laporan keuangan pada UMKM Toko Roti Fadilah. Penelitian ini menunjukan bahwa modal kerja sangat berpengaruh secara signifikan terhadap laba usaha hal tersebut dibuktikan bahwa semakin banyak modal yang digunakan untuk produksi maka semakin tinggi pula hasil produksinya sehingga hal tersebut dapat meningkatkan laba uahanya.
\end{abstract}

Kata Kunci: Modal Kerja, UMKM, Laba Usaha

\section{PENDAHULUAN}

UMKM merupakan usaha yang mampu bertahan ditengah krisis, baik negara maju maupun negara berkembang memaksimalkan peranan UMKM dalam menjaga stabilitas perekonomiannya. Berdirinya usaha kecil dilingkungan masyarakat diharapkan dapat membuka lapangan pekerjaan yang baru dan dapat memberi dampak pada pemerataan pendapatan ditengah masyarakat. Setiap UMKM membutuhkan modal kerja untuk kegiatan operasionalnya setiap - hari. Modal kerja merupakan masalah pokok dan topik penting yang sering terjadi dan sering dihadapi oleh setiap UMKM, karena hampir semua perhatian untuk mengelolah modal kerja dan aktiva lancar yang merupakan bagian yang sangat cukup besar dari aktiva.

Modal kerja dibutuhkan oleh semua UMKM untuk membelanja operasionalnya sehari-hari, misalnya: untuk memberikan presekot pembelian bahan mentah, membiayai gaji pegawai, dan lain-lain, dimana dana yang dikeluarkan tersebut diharapkan dapat kembali lagi masuk ke dalam UMKM pada waktu yang singkat melalui hasil penjualan produksinya. Oleh karena itu, UMKM dituntut agar selalu meningkatkan efisiensi kerjannya sehingga dapat mencapai tujuan yang diharapkan oleh UMKM yaitu mencapai laba yang optimal. Hal ini dudukung oleh penelitian Sugiono (2015) menunjukan bahwa laba usaha selalu mengalami peningkatan hal tersebut di pengaruhi oleh hasil produksinya. Makin tinggi hasil produksi maka semakin tinggi modal usahanya sehingga dapat meningkatkan laba usahanya.

Modal kerja dalam pengukuran tingkat keberhasilan mempunyai peranan yang sangat strategis. Karena dengan pengelolaan yang baik dari modal kerja dapat meningkatkan pendapatan yang menjadi tujuan utama dari setiap UMKM. Dalam menunjang peningkatan pendapatan UMKM hal tersebut harus dikaji labih jauh akan peranan dari modal kerja, dalam rangka kajian tersebut perlu ditelusuri elemen-elemen modal kerja dalam peranannya terhadap peningkatan pendapatan dan sekaligus pembentukan laba. Dalam penelitian Subagio (2017) menyatakan bahwa pengelolaan modal kerja sangat berpengaruh terhadap tingkat keuntungan atau profit UMKM, semakin tinggi modal yang 
digunakan maka semakin tinggi laba yang dihasilkan.

Fadhillah Bakery merupakan sebuah toko yang bergerak dibidang pangan dimana pada toko tersebut memproduksi berbagai macam roti sesuai dengan pemesanan dari para konsumen. Masalah pokok yang sering terjadi pada UMKM Toko Roti Fadilah adalah kurang efektif dalam mengelolah modal kerja untuk biaya operasionalnya setiap hari seperti membeli bahan baku dan peralatan yang di gunakan untuk kelangsungan pembuatan roti.

Penelitian ini difokuskan pada modal kerja yang dimana pada UMKM Toko Roti Fadilah belum efisiensi dam mengelolah dan mengalokasikan modal kerja. Dari uraian di atas maka dapat dirumuskan masalah dalam penelitian ini adalah: (1)Bagaimana penyediaan dan penggunaan modal kerja pada UKM Toko Roti Fadilah? (2)Bagaimana pengaruh penyediaan dan penggunaan modal kerja terhadap peningkatan laba usaha pada UKM Toko Roti Fadilah?

Berdasarkan rumusan masalah yang telah dikemukakan di atas, maka tujuan dari penelitian ini adalah untuk mengetahui penyediaan dan penggunaan modal kerja serta untuk mengetahui pengaruh penyediaan dan penggunaan modal kerja terhadap peningkatan laba usaha pada UKM Toko Roti Fadilah. Sebagai penjelasan di atas, dan berdasarkan rumusan masalah serta tujuan penelitian maka kerangka pikir dapat di gambarkan sebagai berikut :

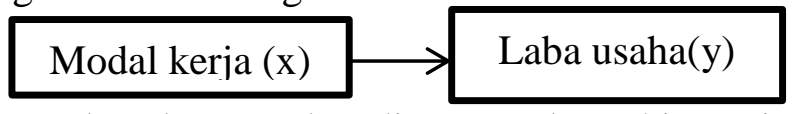

Berdasarkan gambar diatas, terdapat hipotesis yang diajukan dalam penelitian ini yaitu: diduga modal kerja berpengaruh positif terhadap laba usaha.

\section{METODE PENELITIAN}

Jenis penelitian yang digunakan adalah penelitian dengan metode kuantitatif, dan pendekatan deskriptif., yaitu penelitian dengan pendekatan angka-angka baik dalam pengumpulan data dan analisis data. Teknik pengumpulan data berupa wawancara, dokumentasi, observasi, dan studi pustaka.
Dalam penelitian ini sumber data yang digunakan adalah data sekunder berupa laporan keuangan selama lima periode yaitu dari tahun 2013-2017. Untuk menganalisis data mengunakan SPSS versi 24.

Dalam penelitian ini data di analisis menggunakan Uji Normalitas Data, Analisis Koefisien Determinasi dan Regresi Linear Sederhana. Penelitian berlokasi di Toko Roti Fadilah yang beralamat di Jalan Raya Togomas Gang VI Kecamatan Lowokwaru, Kabupaten Malang, Propinsi Jawa Timur. Alasan dalam mengambil lokasi ini yaitu peneliti ingin menganalisis penyediaan dan penggunaan modal kerja dalam meningkatkan laba usaha pada Toko Roti Fadilah.

\section{HASIL DAN PEMBAHASAN}

\section{Tingkat Modal Kerja Yang Terdapat Pada UMKM Toko Roti Fadilah Periode Tahun 2013-2017}

Data laporan keuangan yang di ambil dari UMKM Toko Roti Fadilah yang terletak di Jalan Raya Tlogomas pada periode 2013-2017 adalah, sebagai berikut

\begin{tabular}{|c|l|l|l|}
\hline $\begin{array}{l}\text { Bulan/ } \\
\text { Tahun }\end{array}$ & $\begin{array}{l}\text { aktiva } \\
\text { lancar }\end{array}$ & $\begin{array}{l}\text { hutang } \\
\text { lancar }\end{array}$ & $\begin{array}{l}\text { modal } \\
\text { kerja }\end{array}$ \\
\hline Mar-13 & 31.596 .000 & 8.200 .000 & 23.396 .000 \\
\hline Jun-13 & 38.402 .100 & 7.540 .500 & 30.861 .600 \\
\hline Sep-13 & 30.295 .700 & 9.550 .000 & 20.745 .700 \\
\hline Des-13 & 34.741 .800 & 9.320 .000 & 25.421 .800 \\
\hline Mar-14 & 27.676 .000 & 8.500 .000 & 19.176 .000 \\
\hline Jun-14 & 24.620 .000 & 7.650 .000 & 16.970 .000 \\
\hline Sep-14 & 21.949 .000 & 9.820 .000 & 12.129 .000 \\
\hline Des-14 & 21.134 .500 & 7.650 .000 & 13.484 .500 \\
\hline Mar-15 & 30.274 .000 & 9.750 .000 & 20.524 .000 \\
\hline Jun-15 & 27.900 .000 & 8.350 .000 & 19.550 .000 \\
\hline Sep-15 & 20.076 .000 & 9.250 .000 & 10.826 .000 \\
\hline Des-15 & 21.641 .000 & 8.650 .000 & 12.991 .000 \\
\hline Mar-16 & 29.615 .000 & 8.540 .000 & 21.075 .000 \\
\hline Jun-16 & 26.230 .000 & 9.520 .000 & 16.710 .000 \\
\hline Sep-16 & 23.505 .000 & 8.875 .000 & 14.630 .000 \\
\hline Des-16 & 26.925 .775 & 8.250 .275 & 18.675 .500 \\
\hline Mar-17 & 19.975 .250 & 7.225 .250 & 12.750 .000 \\
\hline Jun-17 & 24.550 .840 & 9.125 .500 & 15.425 .340 \\
\hline Sep-17 & 20.901 .447 & 7.650 .697 & 13.250 .750 \\
\hline Des-17 & 19.232 .275 & 7.112 .125 & 12.120 .150 \\
\hline
\end{tabular}

Dari data tabel diatas dapat diuraikan bahwa, sebagai berikut:

1. Pada tahun 2013 modal kerja bersih pada UMKM Toko Roti Fadilah mengalami 
fluktuasi. Hasil modal kerja yang diperoleh yaitu dari aktiva lancar di kurangi dengan hutang lancar. Pada triwulan pertama di tahun 2013 modal kerja sebesar Rp 23.396.000. Pada triwulan kedua di tahun yang sama modal kerja megalami peningkatan sebesar $\mathrm{Rp} \quad-7.465 .600$ sehingga menjadi Rp 30.861.600. Pada triwulan ketiga di tahun 2013 modal kerja kembali mengalami penurunan sebesar Rp 10.115.900 sehingga menjadi Rp 20.745.700. Pada triwulan terakhir di tahun yang sama modal kerja kembali mengalami peningkatan sebesara Rp -4.676 .100$ sehingga menjadi Rp 25.421.800.

2. Pada tahun 2014 modal kerja yang terdapat pada UMKM Toko Roti Fadilah kembali mengalami fluktuasi, dimana di awal triwulan di tahun 2014 modal kerja sebesar Rp 19.176.000. Pada triwulan kedua di tahun yang sama modal kerja mengalami $\begin{array}{lll}\text { penurunan sebesara } \mathrm{Rp} & 2.206 .000\end{array}$ sehimgga menjadi Rp 16.970.000. Pada triwulan ketiga di tahun 2014 modal kerja mengalami penurunan yang signifikan yaitu sebesar Rp 4.841.000 sehingga menjadi Rp 12.129.000. Pada triwulan terakhir di tahun yang sama modal kerja mengalami peningkatan sebesar Rp 1.355.500 sehingga menjadi sebesar Rp 13.484.500.

3. Pada tahun 2015 modal kerja yang terdapat di UMKM Toko Roti Fadilah mengalami fluktuasi yaitu dimana di awal triwulan di tahun 2015 modal kerjanya sebesar Rp 20.524.000. Pada triwulan kedua di tahun yang sama modal kerja mengalami penurunan sebesar Rp 974.000 sehingga menjadi Rp 19.550.000. Pada triwulan ketiga di tahun 2015 modal kerja mengalami penurunan sebesar $\mathrm{Rp}$ 8.724.000 sehingga menjadi $\mathrm{Rp}$ 10.826.000. Pada triwulan terakhir di tahun yang sama modal kerja mengalami peningkatan sebesar Rp -2.165 .000$ sehingga menjadi Rp 12.991.000.

4. Pada tahun 2016 modal kerja bersih pada UMKM Toko Roti Fadilah mengalami fluktuasi. Hasil modal kerja yang diperoleh yaitu dari aktiva lancar di kurangi dengan hutang lancar. Pada awal triwulan di tahun 2016 modal kerja sebesar Rp 21.075.000. Pada triwulan kedua di tahun yang sama modal kerja kembali mengalami penurunan yang signifikan sebesar $\mathrm{Rp} \quad 4.365 .000$ sehingga menjadi Rp 16. 710.000. Pada triwulan ketiga di tahun 2016 modal kerja kembali mengalami penurunan sebesar $\mathrm{Rp}$ 2.080.000 sehingga menjadi $\mathrm{Rp}$ 14.630.000. Pada triwulan terakhir di tahun yang sama modal kerja mengalami peningkatan sebesar Rp $\quad-4.045 .500$ sehingga menjadi Rp 18.675.500.

5. Pada tahun 2013 modal kerja bersih pada UMKM Toko Roti Fadilah mengalami fluktuasi. Hasil modal kerja yang diperoleh yaitu dari aktiva lancar di kurangi dengan hutang lancar. Pada awal triwulan di tahun 2017 modal kerja sebesar Rp 12.750.000. pada triwulan kedua di tahun yang sama modal kerja mengalami peningkatan sebesar $\mathrm{Rp}-2.675 .340$ sehingga menjadi Rp 15.425.340. Pada triwulan ketiga di tahun 2017 modal kerja mengalami penurunan sebesar Rp 2.174.590 sehingga menjadi Rp 13.250.750. Pada triwulan terakhir di tahun yang sama modal kerja mengalami penurunan sebesar Rp 1.130 .600 sehingga menjadi $\mathrm{Rp}$ 12.120.150.

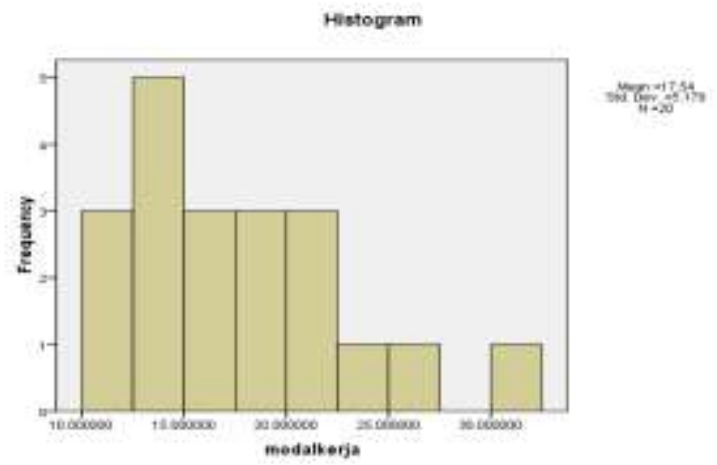

Tingkat Keuntungan Atau Laba Usaha Yang Terdapat Pada UMKM Toko Roti Fadilah Yang Terdapat di Jalan Raya Tlogomas Periode 2013-2017.

\begin{tabular}{|l|c|c|l|}
\hline $\begin{array}{l}\text { Bulan/ } \\
\text { Tahun }\end{array}$ & Pendapatan & $\begin{array}{l}\text { biaya } \\
\text { operasional }\end{array}$ & laba usaha \\
\hline Mar-13 & 72.696 .600 & 39.349 .600 & 33.347 .000 \\
\hline Jun-13 & 82.297 .900 & 39.743 .600 & 42.554 .300 \\
\hline
\end{tabular}




\begin{tabular}{|r|r|r|r|} 
Sep-13 & 42.899 .700 & 13.055 .600 & 29.844 .100 \\
\hline Des-13 & 72.172 .700 & 39.200 .700 & 32.972 .000 \\
\hline Mar-14 & 70.293 .500 & 33.253 .000 & 37.040 .500 \\
\hline Jun-14 & 55.361 .500 & 26.891 .500 & 28.470 .000 \\
\hline Sep-14 & 46.673 .000 & 18.296 .000 & 28.377 .000 \\
\hline Des-14 & 59.461 .000 & 36.157 .000 & 23.304 .000 \\
\hline Mar-15 & 82.641 .500 & 33.898 .000 & 48.743 .500 \\
\hline Jun-15 & 63.747 .000 & 24.468 .000 & 39.279 .000 \\
\hline Sep-15 & 56.356 .000 & 35.001 .000 & 21.355 .000 \\
\hline Des-15 & 62.212 .000 & 40.188 .000 & 22.024 .000 \\
\hline Mar-16 & 48.725 .000 & 20.362 .500 & 28.362 .500 \\
\hline Jun-16 & 53.250 .000 & 23.625 .000 & 29.625 .000 \\
\hline Sep-16 & 64.150 .000 & 36.075 .000 & 28.075 .000 \\
\hline Des-16 & 45.550 .500 & 23.775 .250 & 21.775 .250 \\
\hline Mar-17 & 41.257 .540 & 19.007 .540 & 22.250 .000 \\
\hline Jun-17 & 44.420 .540 & 23.163 .290 & 21.257 .250 \\
\hline Sep-17 & 46.420 .125 & 21.144 .875 & 25.275 .250 \\
\hline Des-17 & 52.352 .350 & 24.011 .850 & 28.340 .500 \\
\hline
\end{tabular}

Dari data di atas menunjukan bahwa tingkat keuntungan yang terdapat pada UMKM Toko Roti Fadilah mengalami flukstuasi selama periode 2013-2017, maka dapat di uraikan sebagai berikut:

1. Pada tahun 2013 di triwulan pertama laba usaha yang terdapat pada UMKM Toko Roti Fadilah sebesar Rp 33.347.000. Pada triwulan kedua di tahun yang sama laba usaha mengalami peningkatan sebesar Rp 9.207.300 sehingga menjadi Rp 42.554.300. Pada triwulan ketiga di tahun 2013 laba usaha mengalami penurunan yang signifikan sebesar Rp 12.710.200 sehingga menjadi Rp 29.844.100. Pada triwulan terakhir di tahun yang sama laba usaha kembali mengalami peningkatan sebesar Rp -3.127.900 sehingga menjadi Rp 32.972.000.

2. Pada tahun 2014 di triwulan pertama laba usaha yang diterima oleh UMKM Toko Roti Fadilah sebesar Rp 37.040.500. Pada triwulan kedua di tahun yang sama laba usaha yang di terima mengalami penurunan sebesar Rp 8.570.500 sehingga menjadi Rp 28.470.000. Pada triwulan ketiga di tahun 2014 laba usaha yang di etrima mengalami penurunan sebesar $\mathrm{Rp}$ 93.000 sehingga menjadi Rp 28.377.000. Pada triwulan terakhir di tahun yang sama laba usaha yang di terima mengalami penurunan sebesar Rp 5073.000 sehingga menjadi Rp 23.304.000.

3. Pada tahun 2015 di triwulan pertama laba usaha yang diterima oleh UMKM toko roti fadilah sebesar Rp 48.743.500. Pada triwulan kedua di tahun yang sama laba usaha yang di etrima mengalami penurunan yang signifikan yaitu sebesar Rp 9.464.500 sehingga menjadi Rp 39.279.000. Pada triwulan ketiga di tahun 2013 laba usaha kembali mengalami penurunan yang signifikan sebesar $\mathrm{Rp}$ 17.924.000 sehingga menjadi $\mathrm{Rp}$ 21.355.000. Pada triwulan terakhir di tahun yang sama laba usaha mengalami peningkatan yaitu sebesar Rp -669.000 sehingga menjadi Rp 22.024.000.

4. Pada tahun 2016 laba usaha yang di terima oleh UMKM toko roti fadilah di triwulan pertama sebesar Rp 28.362.500. Pada triwulan kedua di tahun yang sama laba usaha yang di terima mengalami peningkatan sebesar $\mathrm{Rp} \quad-1.262 .500$ sehingga menjadi $\mathrm{Rp}$ 29.625.000. Pada triwulan ketiga di tahun 2016 laba usaha mengalami penurunan sebesar $\mathrm{Rp}$ 1.550.000 sehingga menjadi $\mathrm{Rp}$ 28.075.000. Pada triwulan terakhir di tahun yang sama laba usaha yang di terima mengalami penurunan sebesara $\mathrm{Rp}$ 6.299.750 sehingga menjadi Rp 21.775.250

5. Pada tahun 2017 di awal triwulan laba usaha yang dimiliki oleh UMKM Toko Roti Fadilah sebesar Rp 22.250.000. Pada triwulan kedua di tahun yang sama laba usaha kembali mengalami penurunan sebesar Rp 992.750 sehingga menjadi Rp 21.257.250. Pada triwulan ketiga di tahun yang sama laba usaha mengalami peningkatan sebesara $\mathrm{Rp} \quad-4.000 .000$ sehingga menjadi $\mathrm{Rp}$ 25.275.250. Pada triwulan terakhir di tahun 2017 laba usaha kembali mengalami peningkatan sebesar Rp -3.065.250 sehingga menjadi Rp 28.340 .500 


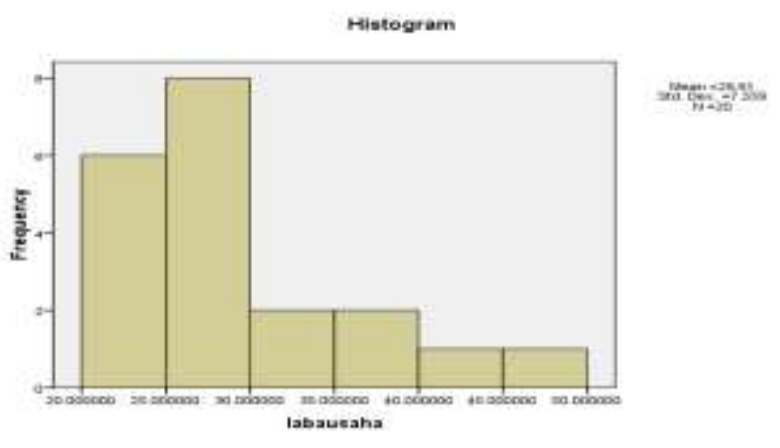

Analisis ini digunakan untuk melihat dan menilai seberapa besar pengaruh modal kerja terhadap tingkat keuntungan atau laba usaha yang di miliki oleh UMKM Toko Roti Fadilah periode 2013-2017.

\section{Hasil analisis}

a. Uji Normalitas

One-Sample Kolmogorov-Smirnov Test

\begin{tabular}{|c|c|c|}
\hline & & $\begin{array}{c}\text { Unstandardi } \\
\text { zed } \\
\text { Residual }\end{array}$ \\
\hline \multicolumn{2}{|l|}{$\mathrm{N}$} & 20 \\
\hline \multirow[t]{2}{*}{ Normal Parameters ${ }^{\mathrm{a}}$} & Mean & .0000000 \\
\hline & Std. Deviation & 5.57214616 \\
\hline \multirow{3}{*}{$\begin{array}{l}\text { Most Extreme } \\
\text { Differences }\end{array}$} & Absolute & .158 \\
\hline & Positive & .158 \\
\hline & Negative & -.097 \\
\hline \multicolumn{2}{|c|}{ Kolmogorov-Smirnov Z } & .707 \\
\hline \multicolumn{2}{|c|}{ Asymp. Sig. (2-tailed) } & .700 \\
\hline \multicolumn{2}{|c|}{ a. Test distribution is Normal. } & \\
\hline
\end{tabular}

Berdasarkan tabel di atas di ketahui bahwa modal kerja dan laba usaha memiliki nilai signifikasi sebesar 0,20 maka dapat di simpulkan bawa kedua variabel tersebut berdistribusi normal karena memiliki nilai signifikasi $>0,05$.

b. Koefisien Determinasi

\begin{tabular}{|l|c|r|r|r|}
\multicolumn{5}{|c|}{ Model Summary $^{\mathbf{b}}$} \\
Model & $\mathrm{R}$ & R Square & $\begin{array}{c}\text { Adjusted R } \\
\text { Square }\end{array}$ & $\begin{array}{l}\text { Std. Error of } \\
\text { the Estimate }\end{array}$ \\
\hline 1 & $.676^{\mathrm{a}}$ & .457 & .426 & 5.724835971 \\
\hline
\end{tabular}

a. Predictors: (Constant), modal kerja

b. Dependent Variable: laba usaha

Berdasarkan data tabel menunjukan bahwa nilai koefisen determinasi sebesar 0,457 yang mengandung pengertian bahwa pengaruh modal kerja terhadap laba usaha adalah sebesar $45,7 \%$ sisanya sebesar $54,3 \%$ hal tersebut menunjukan bawha ada faktor lain yang dapat mempengaruhi tingkat pertumbuhan laba usaha yang terdapat pada UMKM Toko Roti Fadilah.

c. Analisis Regresi Linier Sederhana

Coefficients $^{\mathrm{a}}$

\begin{tabular}{|c|c|c|c|c|c|}
\hline \multirow[b]{2}{*}{ Model } & \multicolumn{2}{|c|}{$\begin{array}{l}\text { Unstandardized } \\
\text { Coefficients }\end{array}$} & \multirow{2}{*}{\begin{tabular}{|c}
$\begin{array}{c}\text { Standardi } \\
\text { zed } \\
\text { Coefficie } \\
\text { nts }\end{array}$ \\
\\
Beta \\
\end{tabular}} & \multirow[b]{2}{*}{$\mathrm{T}$} & \multirow[b]{2}{*}{ Sig. } \\
\hline & B & $\begin{array}{l}\text { Std. } \\
\text { Error }\end{array}$ & & & \\
\hline $1 \quad$ (Constant) & 12.322 & 4.627 & & 2.663 & .016 \\
\hline $\begin{array}{l}\text { modal } \\
\text { kerja }\end{array}$ & .986 & .254 & .676 & 3.889 & .001 \\
\hline
\end{tabular}

a. Dependent Variable: laba usaha

Regresi sederhana didasarkan pada hubungan fungsional ataupun kasual antara satu modal kerja dengan laba usaha. Model persamaan untuk mengetahui regresi linear sederhana sebagai berikut:

$$
\begin{aligned}
\mathrm{Y} & =\alpha+\mathrm{BX} \\
& =12322389,7+0,986 \mathrm{X}
\end{aligned}
$$

Dari hasil tabel diatas yang di tunjukan dalam bentuk persamaan maka dapat di simpulkan bahwa modal kerja berhubungan signifikan dan positif terhadap laba usaha. Hal tersebut dikeranakan bahwa semakin tinggi modal kerja yang digunakan maka semakin tinggi pula laba usaha yang dihasilkan oleh UMKM Toko Roti Fadilah. Hal tersebut dapat katakan bahwa hipotesis satu diterima.

\section{PEMBAHASAN}

a. Penyediaan dan penggunaan modal kerja pada UMKM Toko Roti Fadilah sangat efktif dan efisien. Penggunaan Modal kerja pada UMKM Toko Roti Fadilah yaitu untuk membeli bahan baku serta alat untuk membuat atau memproduksi roti, roti yang dihasilkan pun bermacam - macam sehingga setiap roti mempunyai harganya masing masing. Semakin banyak modal yang digunakan untuk produksi maka semakin tinggi pula hasil produksinya sehingga dapat meningkatkan laba uahanya. Maka diketahui 
bahwa modal kerja yang terdapat pada UMKM Toko Roti Fadilah selalu mengalami fluktuasi yang tidak begitu signifikan. Penyediaan dan penggunaan modal kerja yang efisien dapat mempengaruhi tingat keuntungan atau laba, hal tersebut terjadi pada UMKM Toko Roti Fadilah, yang dimana semakin tinggi modal kerja yang digunakan untuk maka semakin tinggi pula laba usaha yang dihasilkan.

b. Berdasarkan hasil penelitian yang dilakukan pada UMKM Toko Roti Fadilah menunjukan bahwa penyediaan dan penggunaan modal kerja dapat mempengaruhi laba usaha. Hasil analisis menunjukan bahwa modal kerja berhubungan signifikan dan positif terhadap laba usaha. Hal tersebut di lihat dari semakin tingginya modal kerja yang digunakan maka semakin tinggi pula laba usahanya yang terima oleh UMKM Toko Roti Fadilah. Penelitian ini didukung oleh beberapa penelitian terdahulu seperti: Sugiyono (2015) dan Subaigo (2017) yang menyatakan bahwa modal kerja sangat berhubungan erat dengan laba usaha, semakin tinggi modal kerja yang digunakan maka semakin banyak hasil produksinya sehingga dapat meningkatkan laba usaha pada UMKM Toko Roti Fadilah.

\section{SIMPULAN}

Berdasarkan hasil penelitian yang dilakukan pada UMKM Toko Roti Fadilah menunjukan bahwa penyediaan dan penggunaan modal kerja dapat mempengaruhi laba usaha. Pada UMKM tersebut, modal kerja yang di hitung pertiga bulan guna untuk melihat efisiensi kegunaannya selalu mengalami fluktuasi yang tidak begitu signifikan. Semakin tinggi modal kerja yaang di gunakan maka semakin banyak hasil produksi Rotinya hal tersebutlah yang membuat pendapatan atau laba usaha yang terima semakin meningkat.

Hasil penelitian menunjukan bahwa modal kerja berhubungan signifikan dan positif terhadap laba usaha. Hal ini berarti semakin tingginya modal kerja yang digunakan maka semakin tinggi pula laba usahanya yang terima oleh UMKM Toko Roti Fadilah.

\section{DAFTAR PUSTAKA}

Harahap, Sofyan Syafri. 2013. Analisa Kritis Atas Laporan Keuangan. Jakarta: Raja Grafindo Persada.

Jumingan. 2009. Analisis Laporan Keuangan. Jakarta: Bumi Aksara.

Kasmir. 2013. Analisis Laporan Keuangan. Cetakan Keenam. Jakarta: Raja Grafindo Persada.

Sawir, Agnes. 2005. Analisis Kinerja Laporan Keuangan Dan Perencanaan Keuangan Perusahaan. Cetakan Kedua, Jakarta: Gramedia Pustaka.

Sugiyono. 2013 Metode Penelitian Kombinasi (Mixed Methods). Bandung: Alfabeta.

Sutrisno. 2009. Manajemen Keuangan Teori, Konsep Dan Aplikasi. Yogyakarta: Ekonisia

Sugiono. 2015. "Analisis penyediaan dan penggunaan modal kerja pada UMK dalam meningkatkan laba uasaha pada KUB (kelompok usaha bersama) alam lestari” dalam jurnal Prosiding Semiar Nasional Pendidikan Ekonomi \& Bisnis Sabtu, 07 November 2015. Surakarta: Universitas Sebelas Maret Surakarta.

Weston \& E. Copeland. 2010. Manajemen Keuangan. Edisi Revisi Jilid 1. Jakarta: Bina Rupa Aksara Publisher.

Zubir, Zalmi. 2005. Studi Kelayakan Usaha. Jakarta: Lembaga Penerbit Fakultas Ekonomi Universitas Indonesia. 